8. Samaranayake L.P. Sudden onset, acute loss of taste and smell in coronavirus disease 2019 (COVID-19): a systematic review. / L.P. Samaranayake, K.S. Fakhruddin, C. Panduwawala// Acta Odontol Scand. 2020 Aug;78(6). - P. 467-473. doi: 10.1080/00016357.2020.1787505.

9. Wong D.K.C, A review of smell and taste dysfunction in COVID-19 patients. / D.K.C. Wong, H. S Gendeh, H. K. Thong, S.G. Lum, at all. // Med J Malaysia. 2020 Sep;75(5). - P. 574-581.

10. Zhang Y. Smell disorders in COVID-19 patients: role of olfactory training: A protocol for systematic review and meta-analysis. / Y. Zhang, T. Mei, Y. Chen, L. Wang at all. // Medicine (Baltimore). 2021 Feb 26;100(8):e24862. doi: 10.1097/MD.0000000000024862.

DOI https://doi.org/10.30525/978-9934-26-075-9-43

\title{
ВИЗНАЧЕННЯ СТЕХІОМЕТРИЧНИХ КОЕФІЦІСНТІВ РЕАКЦІЇ СОТАЛОЛУ ТА ДІАЗОЛЮ ЧЕРВОНОГО 2Ж
}

\author{
Малецька О. Р. \\ асистент кафедри аналітичної хімії \\ Запорізький державний медичний університет \\ Васюк С. O. \\ доктор фармачевтичних наук, професор, \\ завідувач кафедри аналітичної хіміі \\ Запорізький державний медичний університет \\ Коржова А. C. \\ кандидат фармацевтичних наук, \\ дочент кафедри аналітичної хімї \\ Запорізький державний медичний університет \\ м. Запоріжжя, Украӥна
}

Соталол (N-[4-[1-Гидрок-2-[(1-метилетил)аміно]етил]феніл]метансульфонамид) - синтетичний лікарський препарат, що належить до групи неселективних бета-блокаторів [1, с. 374].

Метою роботи було встановити склад продукту реакції соталолу та діазолю червоного $2 Ж$, який використовували в якості кольорореагента. 
Дослідження проводились на базі відділу експериментальних фармацевтичних досліджень наукового медико-лабораторного центру (НМЛЦ) Запорізького державного медичного університету.

В роботі використовувались наступні реагенти i розчинники: стандартний зразок соталолу, діазоль червоний $2 Ж$, натрію карбонат, метанол та вода очищена.

При виконанні дослідження застосовували наступне обладнання: спектрофотометр «SPECORD-200» (Analytic Jena AG, Німеччина), ваги лабораторні електронні RADWAG XA 210.4Y, ультразвукову баню Sonorex Digitec DT100H., мірний посуд класу A.

Склад продукту реакції встановлювали на основі раніше розробленої методики спектрофотометричного визначення соталолу за реакцією 3 діазолем $2 \%$.

Експериментальним шляхом встановлено, що реакція перебігає у водно-метаноловому середовищі за кімнатної температури з використанням $0,2 \%$ розчину діазолю червоного $2 Ж$ як кольорореагенту 3 утворенням забарвленого продукту реакції з максимумом світлопоглинання при 380 нм.

Для вивчення перебігу фотометричної реакції було проведено спектрофотометричний аналіз розчинів забарвлених сполук, що утворюються в результаті реакцій. В основі даного аналізу лежить спільне використання закону діючих мас та основного закону світлопоглинання. Він включає в себе встановлення складу, стійкості та оптичних характеристик забарвлених продуктів реакції.

Для визначення співвідношення стехіометричних коефіцієнтів між хімічною речовиною і реагентом використовували 2 методи: метод молярних співвідношень (метод насичення) та метод неперервних змін (метод ізомолярних серій) [2, с. 241, 245].

Для виконання аналізу готували розчини реагенту та досліджуваної лікарської речовини однакової молярної концентрації та змішували їх в антибатних співвідношеннях, при цьому загальний об'єм розчину залишався незмінним. У цьому випадку сумарна кількість молей обох компонентів у загальному об'ємі розчину залишається постійною.

Реакції проводили згідно розроблених методик. Вимірювання абсорбції отриманих розчинів проводили при обраній аналітичній довжині хвилі. За отриманими даними було побудовано графік залежності величини оптичної густини від співвідношення об'ємів компонентів ізомолярних серій (рис. 1). 
Отриманні результати показують, що максимальне значення величини оптичної густини продукту реакції прагне до максимуму при взаємодії реагенту з визначуваною речовиною 1:1.

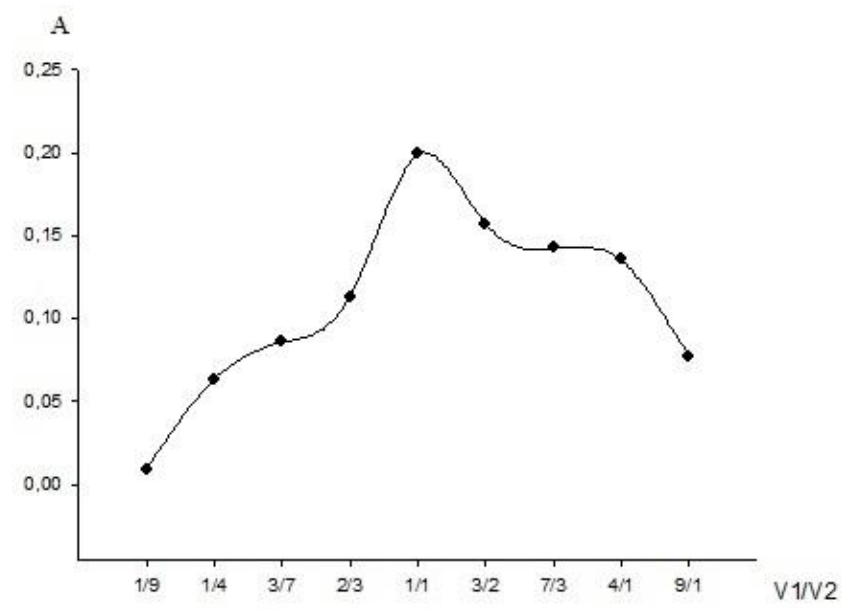

\section{Рис 1. Графік залежності величини оптичної густини від складу ізомолярного розчину (V1 - 0,001 М розчин соталолу, V2 - 0,001 М розчин діазолю червоного 2Ж)}

Найбільш поширеним методом дослідження складу сполук є метод молярних співвідношень (метод насичення). В основі методу лежить встановлення залежності оптичної густини від концентрації одного 3 компонентів реакційної суміші при постійній концентрації другого компонента і навпаки.

Точка перегину на кривій насичення відповідає відношенню концентрацій реагуючих сполук та дорівнює стехіометричному коефіцієнту компонента, концентрація якого змінювалася.

Досліди проводили 3 двома серіями розчинів. Наприклад, в першій серії досліду, у мірні колби ємністю 10,00 мл додавали 0,$20 ; 0,40 ; 0,60$; 0,$80 ; 1,00 ; 1,20 ; 1,40 ; 1,60 ; 1,80$ та 2,00 мл 0,001 М розчину соталолу. До кожної проби додавали по 1,00 мл $0,0004 \mathrm{M}$ розчину діазолю червоного 2Ж та аналізували за загальною методикою. У другій серії досліду проводили аналогічне визначення, але тепер об'єм 0,001 М розчину соталолу залишався незмінним (1,00 мл), а об'єми $0,001 \mathrm{M}$ розчину діазолю червоного $2 Ж$ змінювалися від 0,20 до 2,00 мл. В подальшому 
отримані розчини аналізували за загальною методикою. За отриманими результатами будували криві насичення (рис. 2).

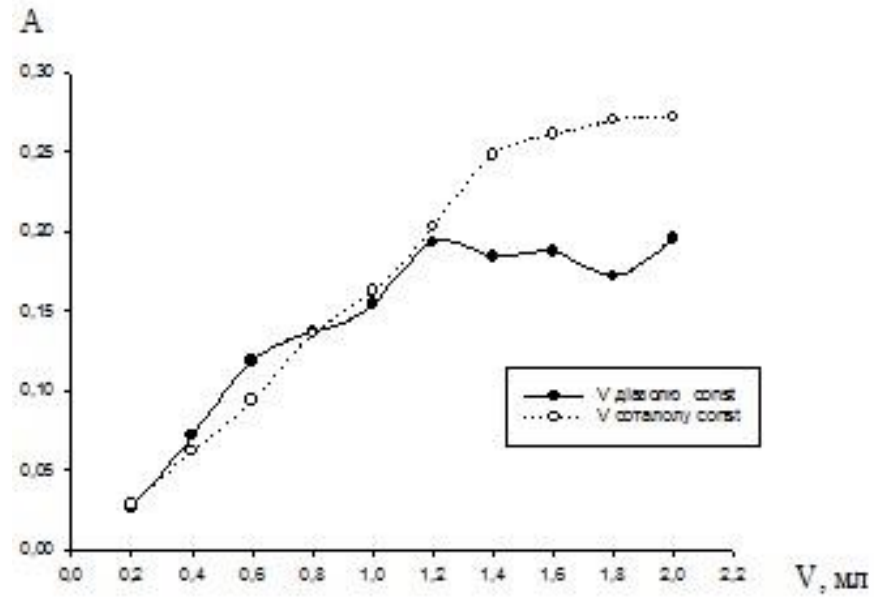

Рис 2. Криві насичення розчину реагента при постійній концентрації розчину соталолу

та постійній концентрації розчину діазолю червоного 2Ж

Визначено коефіцієнти стехіометричних співвідношень методами молярних співвідношень та неперервних змін у системі «реагент лікарська речовина». Доведено, що стехіометричне співвідношення реагуючих компонентів становить 1:1.

\section{Література:}

1. Машковский М. Д. Лекарственные средства. Москва, 2000. T. 1. C. 374.

2. Булатов МИ, Калинкин ИП. Практическое руководство по фотометрическим методам анализа. 5-е изд. Ленинград: Химия; 1986 г. 